\title{
THE RULE OF DECENTRALIZATION EQUALS LOCAL SELF-GOVERNMENT? GENERAL REMARKS ON LOCAL DEMOCRACY IN THE U.S. AN INTRODUCTION TO NEW EXPLORATIONS
}

\author{
Katarzyna Maćkowska*
}

\begin{abstract}
This article refers to a problem of democracy at local levels in the United States. Decentralization of public administration in a federal state raises many questions about local-self government and local democracy. Therefore, a brief introduction is hereby presented, including the following aspects: status of local units, home rule charters, and the managerial system at a local level. When necessary, short references to continental solutions are made in order to explain specific American local structures. Historical determinants are also mentioned in order to illustrate that the U.S. system does not pose an ideal and universal democracy, but there are many provisions that should be considered as a pattern. It is especially significant in the aspect of civil society and its role in contemporary democracy.
\end{abstract}

Key words: local self-government, oul-rule, decentralization in the U.S.

This article is the author's attempt to revert to the problem of American local self-government in order to begin new explorations of this constantly challenging and comprehensive research area. We all understand the meanings of decentralization, local-self government and civil society. We are also fully aware of their significance for a democracy. Nonetheless, as is often the case, the perspective of individual persons depends on their position in society and their economic status. The author understands that such

John Paul II Catholic University of Lublin, Faculty of Law, Canon Law and Administration, mail: kzasepa@kul.pl. 
a statement is tricky and superficial, but the foregoing condition determines how we perceive the reality of our surrounding, notwithstanding the masterpieces on democracy we might be aquainted with. We remain a part of a democratic order, both when we rule others and when we wish to be governed by someone who will have improved our status or will not have diminished it by the end of time in office. And we will never find a silver bullet as a means to balance between the rights and duties of citizens.

It is another general observation that some groups consist of active members who are all involved in a decision-making process, while other groups consist of passive members who avoid making decisions. How to adapt a democratic system to all the potential beneficiaries of the best form of government ever? The utmost importance of this challenge pertains to role of managerial forms within home rule units.

This article is understood as an introduction to the aforementioned problem and as such, it is based on a descriptive methodology. The author hopes to present more detailed research in subsequent publications.

There are no doubts that Americans naturally understand the terminology relating to their local governments and that foreigners have some problems with discovering what particular terms mean and how to compare them to local institutions of their mother-country. From the perspective of the Poles, these distinctions are strenghtened by the fact that the U.S. is a federal state. It causes some confusion because „decentralization” doesn't have to be the same as „non-centralization”.

We all know that many factors have had an impact on American democracy. In the colonial period a number of governmental solutions were implemented only as an effect of practical needs in a new world and these mechanisms were later confirmed on theoretical grounds. This phenomenon can be called bottom - up organization.

The most common term used in the presented aspects is 'local government'. Although it has a quite clear meaning, it also has many aspects, especially when the problem of federalism is raised. As John Kincaid has noted:

'[...] from a constitutional and legal perspective, there is always the question of whether local government is self-government or whether it is a creature of the state. Do local communities owe their existence to the sovereign power, or are local communities the source of sovereign power? Indeed, the very term 'local government', which was apparently coined by 
the English philosopher Jeremy Bentham (1748-1832), came into use to signify local elections of local government officials rather than their appointment by the national or provincial government. For the United States, the people of the states are the source of the sovereign powers exercised by the federal government while, within each state, the people of the state are the sovereign power from which local governments derive their powers. [...] Local autonomy in the United States refers both to local government autonomy and to local community (or civil society) autonomy. These are different, though related, phenomena. Local government autonomy refers to the authority of local governments to exercise self-rule and self-government free from interference from the state government and the federal government. Local community autonomy refers to the authority of citizens in a local community to govern themselves through voluntary institutions of civil society and to engage in public activity nongovernmentally without undue influence from their local and state government as well as the federal government"1.

First, colonists understood the meaning of 'local self-government' in the following aspects:

a) formally, as more sovereignty given by the Crown to the owners in the founding documents - in the case of proprietary colonies (Pennsylvania, Maryland and Delaware) and in the case of Connecticut and Rhode Island;

b) practically, as less influence from the kingdom, which was initially not interested in the colonial process and subsequently not able to control colonies, mainly because of the distance of the colonies.

This must be recognized when a question about the current role of local government is posed. The natural feature of 'independency' of early colonization has influenced the development of an idea that local government constitutes a level primary to states' structure. It was indirectly rooted in Cooley's doctrine in $19^{\text {th }}$ century. Foreigners studying American local government should not be surprised by the concept of home rule and the fact that the U.S. has given an incentive to the worldwide evolution of New Public Management. Whatever the true reason for strengthening

J. Kincaid, Local Autonomy in the United States of America. Report Prepared for the Japan Local Government Center, Easton (Pennsylvania) 1998, p. 2. 
local government is (i.e. the real power of civil society or the federal government aiming at a releasing itself and shifting a part of 'not convenient' competences to other levels), one can always refer to the inherent powers of individuals to local self-government. Undoubtedly, a very optimistic and idealistic version of this concept is recognized by Europeans to have been the common standards implemented in the U.S. (the author claims it to be "Tocqueville's effect"). Connecting the past to the present in the above context, home rule represents a pure form of a contemporary local self-government. One side of this solution is described in the words of E.S. Griffith:

"A written charter is to a city what a written constitution is to a nation. By it the city is endowed with powers. In its provisos are included the outlines of the framework of its government. However much charter and constitution may be modified by usage, nonetheless both stand as legal norms for their respective governments"2.

Another one was marked by W.B. Munro and is still current:

"The American city is a municipal corporation created by the state under its reserved rights of internal sovereignity; it derives all its powers from state laws, and is subordinate in all its activities to the state's authority. [...] To this end, the city is intrusted with only such powers as the legislature may think wise to confer, and even in such grants it acquires no vested rights"3.

Consequently, there are two basic and related problems that have been discussed in American literature:

- what does the local self-government really mean?

- is it a natural right of the people?

Both of these questions may be explained by Fordham's concept of home rule. At this point, one should remember that the legal status of American local government is mostly derived from the concept of judge John Dillon, who stated that a municipal corporation possesses only those powers that are expressly granted or necessarily implied or incident to them. The third category includes powers absolutely essential to the

2 E.S. Griffith, History of American City Government, Vol. I, The Colonial Period, New York 1938, p. 33.

W.B. Munro, The Government of American Cities, New York 1920, p. 53. 
purposes of corporation. Furthermore, J. Dillon required that the courts resolve any disputes as to those powers against corporation ${ }^{4}$. This view resembles the traditional British understanding of local government based on ultra vires rule. In parallel, another judge, Thomas Cooley, developed an idea of the constitutional rights of local citizens to self-government as a basis for limiting the influence of state administration ${ }^{5}$. The abovementioned Fordham's concept has been recognized as a form of compromise between Dillon's and Cooley's views, however the dispute over the status of American local government would never end. When analyzing the historical background, a common and specific way of building of American democracy is discernible. In the process of the creation and evolution of the United States of America, the traditional experiences of England were being modified when new circumstances and necessities were appearing. As a result, the colonists could enact their own laws. Over time however, the relations between federal government and states have predominated in the dispute over local self-government. In 1923 a more conservative attitude to localities' powers was held by the U.S. Supreme Court. The following broad quotation of this verdict seems to be a perfect illustration: 'In the absence of state constitutional provisions safeguarding it to them, municipalities have no inherent right of self-government which is beyond the legislative control of the state. A municipality is merely a department of the state, and the state may withhold, grant, or withdraw powers and privileges as it sees fit. However great or small its sphere of action, it remains the creature of the state exercising and holding powers and privileges subject to the sovereign will. See Barnes v. District of Columbia, 91 U. S. 540, 91 U. S. 544-545. In Mt. Pleasant v. Beckwith, 100 U. S. 514, 100 U. S. 524-525, it was held that, where a municipal corporation is legislated out of existence and its territory annexed to other corporations, the latter, unless the legislature otherwise provides, becomes entitled to all its property and immunities. In the opinion, it is said (pp. 100 U. S. 524525): "Institutions of the kind, whether called cities, towns, or counties, are the auxiliaries of the state in the important business of municipal rule, but they cannot have the least pretension to sustain their privileges or

4 Merriam v. Moody's Executor, 25 Iowa 163, 170 (1868).

5 People ex rel. Le Roy v. Hurlbut, 24 Mich. 44, 52-53 (1871). 
their existence upon anything like a contract between themselves and the legislature of the state, because there is not and cannot be any reciprocity of stipulation between the parties, and for the further reason that their objects and duties are utterly incompatible with everything partaking of the nature of compact"'.

There are a variety of provisions describing the status of localities throughout the federal system of the United States. For instance, according to the New York State Constitution, Article XI, Section 1: "Effective local self-government and intergovernmental cooperation are purposes of the people of the state. In furtherance thereof, local governments shall have the following rights, powers, privileges and immunities [...]."

In $\$ 2(a)$ it is added: "The legislature shall provide for the creation and organization of local governments in such manner as shall secure to them rights, powers, privileges and immunities granted to them by this constitution"7.

Another problem that arises in the above context relates to differences between a deeply decentralized system in a unitary state and the administration in a federal state. It is even more complicated when a status of autonomy is granted to a particular region in a unitary state. As a practical matter, the status of local government within both of these frames might be the same, because formally the lowest levels do not have the attribute of sovereignty. To illustrate this problem it is justified to briefly remark that Polish local administration functions in two shapes: of a territorial administration of the state and as a local self-government. The administrative division of the state was enacted due to ensure the proper organization of a local self-government. In this sense, the priority is given to this second form. Furthermore, the rule of a decentralization is described in the Constitution and therefore, the local self-government is additionally protected and may be directly connected with the sovereignty of people. Despite that, the structure and competences of local governments are imposed from the top down and they remain unitary within the territory of Poland. In most states of the U.S., local inhabitants have a right to

Trenton v. New Jersey, 262 U.S. 182 (1923).

7 New York State Constitution (1938, revised in 2014), https://www.dos.ny.gov/ info/constitution.htm. 
enact a home rule charter and to decide about both the structure and competences of the home rule unit. This is a significant difference because it entitles local inhabitants to determine the shape of structural and functional autonomy and sometimes to disclaim this right through not taking advantage of this.

The revolutionary war period in the history of the United States expanded the meaning of local self - government. According to M. N. Rothbard a default in functioning of political system has caused the voluntary self - government of cooperating units ${ }^{8}$. In those times it was necessary to establish social, 'non - governmental organizations' and associations in order to fight for independence as well as to constitute and petrify new political systems. Modern movements claiming for an expansion of local powers include the legal basis for a cooperation between local units. One of these methods empowering local community autonomy (rights of inhabitants) is comprised of a right to compel localities (structure of government) to a common venture. Such an instrument may only seemingly be recognized as a poor form of local self - government. There is always a risk that citizens will be forced to finance and carry on activities instead of inefficient state or federal governments. That raises a general question about a civil society and the potential danger of misuse by unscrupulous and unskilled public administration (including institutions of local selfgovernment contra the local community).

From the point of view of community and local people, the idea of local self-government does not have to be identical to the decentralization of public administration. It is actually the question about what people want to do. If they would like to decide actively about local affairs - assuming their full understanding that they have to look for their own resources - they should be legally entitled to do so. If they are passive and would rather that the state administration managed their local affairs, they may rely only on the activity of this administration. What really matters and poses a genuine local democracy is actually the choice and in most American states such a choice is legally available. A classic mode of granting the home rule status is incorporation which is understood as ordaining,

8 M.N. Rothbard, Conceived in Liberty, Vol. III, Advance to Revolution, 17601775, New York 1976, p. 138. 
establishing and adopting a charter for a municipal government. Furthermore, to ensure the efficiency of public administration, a managerial system has been developed since the beginning of the $19^{\text {th }}$ century. It ought to be a specific way of curing the bad sides of democracy. Where the mayor is elected at large, some political implications and determinants appear that are not necessarily connected to a proper management. Therefore, local citizens have a right to implement a council - manager form. In the example of the Fort Collins charter, this scheme is based on the principle that executive duties are performed by a highly qualified, educated and experienced officer, in fact replacing a mayor whose position is limited to one of the councilmen. Obviously, the appointment of managers - with such powers as appointing and removing all heads and service areas, preparing the budget, enforcing the laws and city ordinances and presiding over the administrative branch (art. III, Section 2$)^{9}$ - without any democratic methods raises the question about their mandate. This problem is solved normatively by the general clause that all powers of the city and the determination of all matters of policy is vested in the Council (art. II, Section 5).. In effect, a city manager becomes accountable to the Council. The Mayor performs only ceremonial tasks, remains primus inter pares at the Council, represents the Governor for purposes of military law and finally executes legal instruments requiring his signature (art. II, Section 4). It should be also noted that the term of office of the mayor shall be two years and that of remaining councilmen should be four years. These offices are renewable without any time restrictions (art. II, Section 1(d)). This remark leads to the problem of imposing limits on repeated tenures. In Poland there is a serious debate on the introduction of such limits. The ideological background includes a necessity of strengthening a local self-government and providing the community with a real choice at the time of election. The reason is that in some small localities there are no rivals in an election campaign, not because a mayor performs his function effectively but because the community is passive and does not believe that it may change the situation. On the other side, opponents of this solution claim that there are mayors really respected by local inhabitants for how they manage local

9 On the example of Fort Collins Municipal Charter, https://library.municode.com/ co/fort_collins/codes/municipal_code?nodeId=FOCOCH. 
affairs and allowing the term of office to be renewable only once would be against local demands.

Getting back to the main thread it must be stressed that the city manager is appointed for an indefinite term and may be removed by a majority vote of the councilmembers (art. III, Section 4). The specifics of this position resembles relations between a board of directors and chief executive officer in companies and actually it had been derived from managerial experience in the private sector. That is why the term "CEO" is rooted in public administration nowadays. For instance, in Santa Barbara the governing body is the board of supervisors responsible for efficient and effective management (art. X, Section 2-69) ${ }^{10}$ and that "has ultimate authority and control over county policy, budgetary matters, and strategic direction. The board exercises overall oversight of county operations and officers as required by California law". (art. X, Section 2-69). What modifies this basic rule of law in California is just the position of CEO and its executive authority to manage and direct the operations of the county, (art. X, Section 2-69). This position is exempt from the civil service but it requires high qualifications, i.e. knowledge and skills in public administration and finance, knowledge of organizational principles and relationships, leadership and management skills and ability to motivate people to work together cooperatively, (art. X, Section 2-70). How then is this issue connected to democracy? It is commonly recognized that an agreement of the majority does not have to necessarily be identical to a common good. It is also widely observed that political issues influence public administration, even though in some cases the law requires political impartiality. Today we mostly associate both efficiency and effectiveness with the common good. It appears that the best methods of fulfilling those purposes are based on forms of management that are used in the private sector. Accordingly, the community is professionally provided with public services and is represented by the governing body which stays accountable for a proper manager's appointment.

Furthermore, the legal status of American counties should be considered in the context of conflicts arising in the process of democratization

10 On the exanple Santa Barbara County Code, https://ibrary.municode.com/ca/ santa_barbara_county/codes/code_of_ordinances?nodeId=CH2AD. 
at a local level. Though the local system is not unitary, the counties are the most common general local unit covering all states with the exception of Connecticut and Rhode Island (where they are recognized as geographical areas). In Louisiana they are called parishes and in Alaska - boroughs. Historically, the counties have been established in the southern colonies because isolated plantations had required a different, more centralised type of government ${ }^{11}$. Traditionally, counties remain to be administrative arms of the states but because of their ineffectiveness they were partially granted more autonomy by allowing them to apply for home rule. For example, according to General Laws of Massachusetts such a charter county has a legal personality and may sue and be sued, enter into contracts, acquire and dispose of land and personal property (Chapter 34A, Section $16(\mathrm{~A})^{12}$. It has structural and personal autonomy that results in a right to create, alter, abolish offices, positions and employment, establish their qualification and define their powers and duties (Section 16(A) (i)) with reference that this grant of powers shall be construed as liberally as possible, (Section $16(\mathrm{C})$ ). Furthermore, it has functional autonomy illustrated by a right to adopt, amend, enforce and repeal ordinances and resolutions as well as to regulate its internal affairs, (Section 16(A)(i) and (ii). Finally, it has fiscal autonomy but subject to Dillon's rule, (Section 16(A)(iv)). In consideration of all of these factors one should conclude that a home rule county obtains a new identity of a local self-government unit. The question is then if this situates home rule counties in a position to be supplementary localities to incorporated towns, townships and municipalities or would they become rivals of such traditional self-governmental areas. The answer seems to be clear: "Nothing in this chapter shall be construed to impair or diminish or infringe on the powers and duties of cities and towns under the General Laws. It is the intent of this chapter only to permit cities and towns to employ services and facilities of the county for more effective, efficient and adequate provision of services if and when cities and towns may deem it desirable to do so. Cities and towns are and shall remain the broad repository of local police power in

11 T. Langer, Stany w USA. Instytucje - praktyka - doktryna, Warsaw, 1988, p. 307.

12 General Law of Massachusetts, Chapter 34A, https://malegislature.gov/Laws/GeneralLaws/PartI/TitleVI/Chapter34A. 
terms of the right and power to legislate for the general health", (Section 16(B)). And further: "[...] Based on the need to develop effective services to meet problems which cross city or town boundaries and which cannot be met effectively on an individual basis by the cities and towns, or the state, this chapter shall be construed as intending to give the county power to establish innovate programs and to perform such regional services as the Constitution of the Commonwealth of Massachusetts and the General Law permit and to establish such other programs and services as may from time to time be permitted", (Section 16(C)).

This aspect is strictly connected to a problem of multi-level local self - government. In Poland, for instance, opponents of counties claim that most local services are provided by towns and that voivodeships connect local self-government and state administration in a sufficient measure. Therefore, the existence of counties is not necessary, especially since they do not improve, but rather complicate the performance of local tasks. In the United States vesting counties with more self-governmental powers have resulted in new conflicts between municipalities/other home rule units and counties because counties competed with municipalities. In this traditional scheme, there are two forms of vertical conflicts: between county local government and municipal local government and between county local government and the municipal local community. When the county is granted home rule a new type of conflict may appear, i.e. between county local community and municipal local community. In my opinion it should not be considered as an obstacle because it refers to the activity of direct democracy. Nevertheless, the problem of the 'dark ages' should be recalled in this context. In the second half of the $19^{\text {th }}$ century, in a time of a rapid economic growth, both the strong decentralization of local governments and its connection to private sectors according to the rule that business is always good led to ineffectiveness and the appearance of a net of influences between politicians and local officers at the expense of local communities. T. Langer stressed in his publication that it shows how the democracy acted against itself ${ }^{13}$. Notwithstanding such a danger, there are no doubts that - as it is noted in Polish literature - a procedure of creation, restructuring and liquidation of American local governments

13 T. Langer, op. cit., p. 307. 
petrifies their democratic character, because all these legal tools can be used by active communities ${ }^{14}$.

In American publications the terminology commonly used embraces both democratic meanings: an initiative and an immunity which were introduced by G.L. Clark in his famous publication 'A Theory of Local Autonomy'. Accordingly, the initiative is a power of local government to act in a purposeful goal-oriented fashion without the need for a specific grant of power ${ }^{15}$. The immunity is the power of localities to act without fear of the oversight authority of higher tiers of the state ${ }^{16}$. As a result we have four theoretical combinations of levels of democracy among home rule units: initiative and immunity, initiative and a lack of immunity, immunity and a lack of initiative and finally no initiative and no immunity. In practice, there are no local governments with no initiative and no immunity but with a very active community using all available resources to decide about local affairs as well as local governments with initiative and immunity but with passive local communities not interested in using available home rule tools. Moreover, the initiative may be understood as a blanket authorization to satisfy new local needs without a necessity of frequent modifications of state and local provisions.

If we focus on a pragmatic and functional view on the idea of local democracy, then we should not forget about a problem of liability. That is why local officers should pay a bond insurance. Obviously, it is a practical difficulty to distinct between malfeasance, intentional error and unintentional error, but local inhabitants are capable of using the following legal remedies against administration: injunction, certoriari and prohibition, indictment, contractual responsibility and torts ${ }^{17}$. The American understanding of public administration is different than the European one and therefore we may find a quite exotic illustration of the above problem. It is somehow related to a category of so called frivolous lawsuits. For

14 W. Kisiel, Władze lokalne w Stanach Zjednoczonych Ameryki. Pragmatyczne zróżnicowanie, Cracow 1995, p. 7.

15 G.L. Clark, A Theory of Local Autonomy, „Annals of the American Association of Geographers", No 74, p. 197. W. Kisiel, Władze..., p. 33. J. Kincaid, Local..., pp. 21-22.

16 G.L. Clark, A Theory..., p. 198. W. Kisiel, Władze..., p. 33. J. Kincaid, Local..., pp. 21-22.

17 W. Kisiel, Władze..., p. 52. 
example, the living will is an individual's declaration regarding life-sustaining procedures. It happened in Pensylvania that a police officer attempted to save a life of a woman who desired not to be revived, and what resulted was a case before the court and new legal provisions the role of which is to protect policemen and allow them to give assistance to injured people even though they have a living will ${ }^{18}$. Generally, it pertains to ethics and the moral aspect of public duties. In the U.S. there are different meanings of responsibility, accountability and liability. When we consider non-legal and non-political determinants of democracy, our responsibility, accountability and liability as representatives, voters, officers and activists remain the best protection of democracy. Regarding this problem one solution should be copied from American legislation and enacted in Poland. It is one that requires that voting by councilmen is recognised as a duty, not a right. For instance, according to the General Statutes of North Carolina, $\$ 160 \mathrm{~A}-75$ : No member shall be excused from voting except upon matters involving the consideration of the member's own financial interest or official conduct or on matters on which the member is prohibited from voting [...] a failure to vote by a member who is physically present in the council chamber [...] shall be recorded as an affirmative vote ${ }^{19}$. On the other hand, we should also treat our right to vote as a duty.

Let me conclude with a brief appraisal that American democracy remains a specific system which is rooted in practical lessons gained from the colonial period and systematically modified according to new circumstances. Theoretically, decentralization is equal to local-self government but to define the term of local-self government has never been an easy task. When it is limited to local elections and the provision of public services by representative institutions, then it is not sufficient to identify it with the most clear pattern of democracy - the participatory one. Democracy, however, should allow people not to be involved in a decision-making process. And these paradoxes and equivocations would be a starting point for further explorations regarding local general administration and school management.

18 J. Kincaid, Local..., p. 30.

19 http://www.ncleg.net/EnactedLegislation/Statutes/PDF/BySection/Chapter_160 A/GS_160A-75.pdf. 


\section{REFERENCES}

Clark G.L., A Theory of Local Autonomy, „Annals of the American Association of Geographers", No 74.

Griffith E.S., 1938, History of American City Government, Vol. I, The Colonial Period, New York.

Kincaid J., 1998, Local Autonomy in the United States of America. Report Prepared for the Japan Local Government Center, Easton (Pennsylvania).

Kisiel W., 1995, Władze lokalne w Stanach Zjednoczonych Ameryki. Pragmatyczne zróżnicowanie, Cracow.

Langer T., 1988, Stany w USA. Instytucje - praktyka - doktryna, Warsaw.

Munro W.B., 1920, The Government of American Cities, New York.

Rothbard M.N., 1976, Conceived in Liberty, Vol. III, Advance to Revolution, 1760 - 1775, New York. 